\title{
Territorial behaviour in southern impala rams (Aepyceros melampus Lichtenstein)
}

\author{
C. M. Oliver ${ }^{1}$ J. D. Skinner ${ }^{1}$,D. Van der Merwe ${ }^{2}$ \\ ${ }^{1}$ Veterinary Wildlife Unit, Faculty of Veterinary Science, Onderstepoort, 0110, South Africa and ${ }^{2}$ Agricultural Research \\ Council, Onderstepoort Veterinary Institute, Private Bag X5, Onderstepoort, 0110, South Africa
}

\begin{abstract}
The role of territoriality was investigated by studying 25 impala rams at a reserve in the Waterberg region of South Africa $\left(23^{\circ} 45^{\prime} \mathrm{S}, 28^{\circ} 23^{\prime} \mathrm{E}\right)$. Mean territorial tenure was 67.25 days (range 23-99), with a mean territory size of $21.0 \pm 11.27 \mathrm{ha}$, compared with home ranges of $34.1 \pm 9.03$ ha for territorial rams and $58.8 \pm 33.35$ ha for bachelor rams, using the fixed kernel method. Territory boundaries remained constant, whilst the area surrounding important features such as water holes, appears to be neutral in terms of territoriality. The rut, as evidenced from peaks in chasing and roaring, lasted for 2 months from 10 April to 10 June 2001, with intensified behaviour including matings observed from 16 May to 4 June 2001. Territorial rams chase and roar more than bachelors. Flehmen and display behaviours are performed by all rams, whilst fights and other reproductive behaviours are generally rare. Bachelors browse more than territorial rams. Only bachelors spar and allogroom, and orally groom themselves more than territorial rams.
\end{abstract}

\section{Résumé}

On a étudié le rôle de la territorialité en observant 25 mâles impala dans une réserve de la région de Waterberg, en Afrique du Sud $\left(23^{\circ} 45^{\prime} \mathrm{S}, 28^{\circ} 23^{\prime} \mathrm{E}\right)$. La conservation d'un territoire durait en moyenne 67,25 jours (23-99 jours) et celui-ci mesurait en moyenne $21.0 \pm 11.27$ ha, comparé au domaine vital qui est de $34.1 \pm 9.03$ ha pour les mâles territoriaux et de $58.8 \pm 33.35$ pour les jeunes mâles solitaires, en utilisant la méthode de Kernel. Les limites des territoires restaient constantes, alors que l'aire entourant les éléments importants comme les points d'eau semble neutre en termes de territorialité. Le rut, mis en évidence par des pics de poursuites et de cris, a duré deux mois $(10$ avril -10 juin 2001$)$ et ce comportement s'est intensifié, avec des accouplements observés entre le 16 mai et le 4 juin. Les mâles territoriaux se lancent dans des poursuites et des cris plus que les solitaires. Le flehmen behaviour et les exhibitions sont pratiqués par tous les mâles, alors que les combats et les autres comportements reproducteurs sont en général rares. Les célibataires broutent plus que les mâles territoriaux.
Seuls les célibataires feignent des combats et se grooment l'un l'autre, et ils se grooment eux-mêmes avec la bouche plus souvent que les mâles territoriaux.

\section{Introduction}

Impala (Aepyceros melampus Lichtenstein) are extremely important to the game ranching industry of southern Africa. As a result, knowledge of their reproductive behaviour is important to help managers decide on the numbers of rams required, nature and size of territories, and the length of territorial tenure to ensure high fecundity.

Research carried out on territoriality in impala can be split into two main sites: equatorial east Africa and southern Africa, with significant variation between seasons (Skinner \& Skinner, 2001). Rams are territorial throughout their range, but this is far more apparent in the contracted rutting period in southern Africa. What is most desirable in a territory is yet to be determined, but access to key resources such as food and water, which in turn attract females, is important. Jarman (1979) suggested that more attractive territories contained the greatest diversity of vegetation, as well as other significant assets such as water sources, salt licks and shade trees. Dasmann \& Mossman (1962) note that areas around water holes may become 'neutral', removing excessive aggression.

Rams show complex territorial behaviour (Jarman, 1979), advertizing their presence in many ways, including roaring and chasing. Aggressive behaviour between rams is often highly ritualized (Murray, 1982a), with fights resulting in serious injury being rare. Almost all matings are limited to territorial rams (Murray, 1982a). Impala are mixed feeders (Hofmann \& Stewart, 1972), but territorial rams had a poorer quality diet than ewes (Van Rooyen \& Skinner, 1989), probably because of the less time spend for plant selection. Impala groom in response to the irritation from ectoparasites. Territorial rams never engaged in allogrooming, whilst they orally groomed themselves less than ewes or 
bachelors (Mooring, McKenzie \& Hart, 1996), and therefore support a higher density of ticks.

The aim of the present study was to investigate territoriality in South African impala with its short breeding season, specifically how frequently status amongst rams changes during rut, pre-rut and post-rut.

\section{Materials and methods}

The study was conducted at Touchstone Game Ranch, in the Waterberg mountain region, South Africa $\left(23^{\circ} 45^{\prime} \mathrm{S}\right.$, $28^{\circ} 23^{\prime} \mathrm{E}$ ). This is the Waterberg Moist Mountain Bushveld habitat, part of the savannah biome (Van Rooyen \& Bredenkamp, 1996). The study site was approximately 200 ha and consisted of a flat, open valley surrounded by steep bushy slopes. Annual rainfall is $650-900 \mathrm{~mm}$, temperatures ranging from -6 to $39^{\circ} \mathrm{C}$ (mean $18^{\circ} \mathrm{C}$ ).

Nine male impalas were immobilized using combinations of $1.5 \mathrm{mg}$ etorphine hydrochloride (M99 ${ }^{\mathbb{B}}$; Virbac, Centurion, South Africa) or $20 \mathrm{mg}$ fentanyl (Kyron, Johannesburg, South Africa), and $15 \mathrm{mg}$ xylazine hydrochloride (Rompun $^{\circledR}$; Kyron) (D.G. Meltzer, pers. comm.). Each animal was fitted with a coloured collar, whilst sixteen other rams were identified by using a combination of horn length and shape, facial markings, and distinctive scars and body marks. Only those rams that were $\geq 2.5$ years old were studied, as identified by the fully formed lyre-shaped horns.

Observations from a vehicle took place from 5 February to 28 September 2001 and were carried out at a range of 20-200 m. First, on entering the study site, the whole area was traversed, and each ram present and with which it was associated, recorded. Rams were assessed as being 'together' if they were within approximately $20 \mathrm{~m}$ of another impala, or were clearly interacting with an individual or members of a group. The location of the rams was also recorded at this time. This was done having initially used a Garmin $12^{\circledR}$ Global Positioning System (GPS) (Garmin International Inc, Kansas City, MO, USA) to map out the road network in the valley, as well as identifying notable features. The animals were placed in squares of $1 \mathrm{~cm}: 27.5 \mathrm{~m}$, using compass bearings taken from two known objects to the ram. Locations of the rams were noted a maximum of three times a day, and thus on average $5 \mathrm{~h}$ apart, to ensure independence.

All data were then analysed with respect to whether rams were territorial or non-territorial. This was done by working out the proportion of sightings a ram spent alone, with ewes, or with rams on a particular day. It was then graded as being 'territorial' when the proportion of sightings spent with rams was less than that with ewes, and a 'bachelor' when with rams more than with ewes. New categories were devised for situations where data did not fit the field observations. An 'aspirant' was a non-territorial ram which was alone but testing the territorial rams to see if it could force them off and therefore showed some territorial behaviour. In the same way, an 'indeterminate' was a ram which had recently lost its territory and was yet to join a bachelor herd, thus showing a lag in the data changing from territorial to bachelor status. 'Relaxed' described the situation when territoriality relaxed later in the year, and as a result, territorial rams began to show the behaviour of non-territorial rams, becoming more tolerant again to other rams in the area.

Location data were converted to points on a map using the ArcView $^{\circledR}$ GIS software (version 3.2) (ESRI, Redlands, CA, USA). Home range analysis was then carried out by using the Animal Movements and Ranges extension (Hooge \& Eichenlaub, 1998) in conjunction with the Spatial Analyst extension (version 1.1) of $\mathrm{ArcView}^{\circledR}$. The most commonly used method in the past has been the minimum convex polygon (MCP) method, yet it frequently overestimates home range size (Worton, 1987; Boulanger \& White, 1990). A more modern alternative is the fixed kernel method that gives more accurate areas (Seaman \& Powell, 1996).

After the initial morning pass through the study site, the ram that had been observed least was selected. Starting with an initial observation (time 0 ), scan sampling was used to record ram behaviour every $4 \mathrm{~min}$ for $1 \mathrm{~h}$, as used by Jarman \& Jarman (1973). After this, the study site was again traversed, and observations repeated on a new focal animal. In addition to scan sampling, focal data were also collected whereby short lasting behaviours were recorded as they happened over the hour-long observations. This method was used to put a frequency of incidences on short behaviours, by recording either the length or number of times they occur, when the behaviour involves definite discrete actions, such as roaring or rearing. Observations were made from sunrise to sunset.

Behaviour data processing was carried out using the SAS $^{\circledR}$ statistical programme made available by SAS Institute Inc. (Cary, NC, USA), and was analysed by fitting a general linear model (GLM) to the data containing predictor variables, a repeated-measures variable, and interactions between the two. We assumed normal distribution for these analyses, because each dependent variable was calculated from a minimum of approximately 80 records which therefore satisfies the conditions set by the central limit theorem. Home range 
and territory size data were compared using a paired $t$ test. To compare home range size obtained using territorial and bachelor rams, the assumptions of normality and equal variance were not met, and therefore a Mann-Whitney rank-sum test was applied to the data.

\section{Results}

The frequency of chases per day (rams chasing other rams, ewes or young males) and frequency of roars per day, both accurately reflected rut behaviour. Using both parameters, the rut was taken as occurring when these peaked from 10 April to 10 June 2001.

Of 25 known rams, eight were non-territorial for the whole period, and eight showed definite territoriality for a part thereof. Of these rams, three set up territories before the rut and lost them during the rut, one held its territory within the rut, and four took over territories during the rut and held them until territoriality relaxed. They were territorial for an average of 67.25 days (range 23-99). Two other rams displaced the original four owners and remained territorial for an average of 7.5 days, before being removed by the final four territorial incumbents, and were observed for less than ten observation days in total (Table 1).
The other seven known rams showed a mixture of statuses or were only in the study site for a short time period. Mean aspirant behaviour shown by seven rams (one showed aspirant behaviour twice) was 6.13 days $(n=8)$. Four aspirant rams successfully became territorial, and three remained non-territorial. Mean indeterminate behaviour was shown by five rams for 6 days.

Table 2 shows the mean home range and territory sizes of rams. There is a significant difference between home range and territory sizes of territorial rams (paired $t=$ 4.518 , d.f. $=7, \mathrm{P}=0.003$ ), but not between territorial and bachelor ram home ranges (Mann-Whitney $t=55$, $\mathrm{n}=8, \mathrm{P}=0.20)$.

Four territories were held within the study site, regardless of the occupier. The dates of territory takeovers are often hard to establish accurately as the event was not always seen. Dates when rams took over and lost or gave up their territories are shown in Table 1 along with the process by which it happened, where observed. Matings by three rams on four occasions were observed, and mountings as well as genital licking of ewes was also observed. The territorial status of the rams showing reproductive behaviour was established and is displayed in Table 3.

Table 1 Dates and length of observed territoriality, with method of territory loss where observed

\begin{tabular}{|l|l|l|l|l|}
\hline First date of territoriality & Last date of territoriality & Length (days) & Ram no. & Method of territory loss \\
\hline $07 / 02 / 2001$ & $16 / 05 / 2001$ & 99 & 4 & Lost fight with ram 15 \\
\hline $14 / 02 / 2001$ & $12 / 05 / 2001$ & 88 & 24 & $?$ \\
\hline $26 / 02 / 2001$ & $16 / 05 / 2001$ & 80 & 3 & Chased by ram 4 \\
\hline $14 / 05 / 2001$ & $21 / 05 / 2001$ & 7 & $20^{\text {a }}$ & $?$ \\
\hline $14 / 05 / 2001$ & $07 / 06 / 2001$ & 23 & 2 & Chased by ram 25 \\
\hline $17 / 05 / 2001$ & $25 / 05 / 2001$ & 8 & $1^{\text {a }}$ & $?$ \\
\hline $21 / 05 / 2001$ & $20 / 07 / 2001$ & 61 & 19 & Relaxed \\
\hline $21 / 05 / 2001$ & $25 / 07 / 2001$ & 66 & 22 & Relaxed \\
\hline $05 / 06 / 2001$ & $07 / 08 / 2001$ & 64 & 16 & Relaxed \\
\hline $07 / 06 / 2001$ & $02 / 08 / 2001$ & 57 & 25 & Relaxed \\
\hline${ }^{a}$ Only ten observation days or less are available for this animal. & & \\
\hline
\end{tabular}


Table 2 Mean size of home range and territory size for territorial and bachelor rams calculated using a 95\% fixed kernel method

\begin{tabular}{|l|l|l|l|}
\hline & Bachelor home range size (ha) & Territorial home range size (ha) & Territory size (ha) \\
\hline Mean & 58.8 & 34.1 & 21.0 \\
\hline Standard deviation & 33.35 & 9.03 & 11.27 \\
\hline
\end{tabular}

Table 3 Territorial status of rams performing mating and sexual behaviours towards ewes

\begin{tabular}{|c|c|c|c|}
\hline Ram no. & Date & Behaviour & Territorial status \\
\hline 15 & 09/04/2001 & Mount & Aspirant \\
\hline \multirow[t]{2}{*}{2} & $16 / 05 / 2001$ & Mount & Territorial \\
\hline & $23 / 05 / 2001$ & Mount & Territorial \\
\hline \multirow[t]{2}{*}{9} & $16 / 05 / 2001$ & Mount & Aspirant \\
\hline & $16 / 05 / 2001$ & Copulation & Aspirant \\
\hline \multirow[t]{2}{*}{20} & $16 / 05 / 2001$ & Mount & Territorial \\
\hline & $16 / 05 / 2001$ & Copulation & Territorial \\
\hline \multirow[t]{5}{*}{22} & $21 / 05 / 2001$ & Mount & Territorial \\
\hline & $04 / 06 / 2001$ & Mount & Territorial \\
\hline & $04 / 06 / 2001$ & Lick female & Territorial \\
\hline & $21 / 05 / 2001$ & Copulation & Territorial \\
\hline & $04 / 06 / 2001$ & Copulation & Territorial \\
\hline \multirow[t]{2}{*}{ Juvenile male $^{\mathrm{a}}$} & $16 / 05 / 2001$ & Mount & Juvenile \\
\hline & 04/06/2001 & Mount & Juvenile \\
\hline
\end{tabular}

The date of first observed mating was 16 May 2001, 9 days after the full moon. The first observed birth of impala lambs on the reserve was on 29 November 2001, 197 days after the first observed mating. Later neonates were estimated to have been born on 12 December 2001, giving conception dates between 27 May and 1 June, following Skinner \& Smithers (1990) (195-200 days).
For behaviour analysis, seven rams showing territorial behaviour for part of the year, and seven bachelors (nonterritorial for the whole year), were observed. Using scan and focal data, the percentage and length of time spent on daily activities, or the number of times they were performed, was estimated. Significant differences found between rams are displayed in Table 4 . 
Table 4 Significant differences found in different behaviours performed by territorial and bachelor rams in the rut and non-rut

\begin{tabular}{|c|c|c|}
\hline Behaviour (time period) & Observed differences found between rams & Reported statistics \\
\hline Chase (rut) & $\mathrm{T}>\mathrm{B}$ & $\mathrm{F}=4.91$, d.f. $=12, \mathrm{P}=0.047$ \\
\hline Chased (rut) & $\mathrm{T}<\mathrm{B}$ & $\mathrm{F}=5.04$, d.f. $=12, \mathrm{P}=0.044$ \\
\hline Chased (non-rut) & $\mathrm{T}<\mathrm{B}$ & $\mathrm{F}=5.60$, d.f. $=12, \mathrm{P}=0.036$ \\
\hline Roaring (rut) & $\mathrm{T}>\mathrm{B}$ & $\mathrm{F}=5.86$, d.f. $=12, \mathrm{P}=0.032$ \\
\hline Roaring (non-rut) & $\mathrm{T}>\mathrm{B}$ & $\mathrm{F}=9.63$, d.f. $=12, \mathrm{P}=0.009$ \\
\hline Sparring (non-rut) & $\mathrm{T}<\mathrm{B}$ & $\mathrm{F}=6.55$, d.f. $=12, \mathrm{P}=0.025$ \\
\hline Browse (non-rut) & $\mathrm{T}<\mathrm{B}$ & $\mathrm{F}=4.24$, d.f. $=12, \mathrm{P}=0.062$ \\
\hline Browse (ignoring rut) & $\mathrm{T}<\mathrm{B}$ & $\mathrm{F}=6.94$, d.f. $=12, \mathrm{P}=0.022$ \\
\hline Allogrooming (rut) & $\mathrm{T}<\mathrm{B}$ & $\mathrm{F}=6.19$, d.f. $=12, \mathrm{P}=0.029$ \\
\hline Allogrooming (non-rut) & $\mathrm{T}<\mathrm{B}$ & $\mathrm{F}=5.25$, d.f. $=12, \mathrm{P}=0.041$ \\
\hline Grooming (rut) & $\mathrm{T}<\mathrm{B}$ & $\mathrm{F}=8.99$, d.f. $=12, \mathrm{P}=0.011$ \\
\hline
\end{tabular}

Both territorial and bachelor rams performed displays, and fighting, although rarely observed, was also carried out by rams of both statuses. The same can be said for the reproductive behaviours such as flehmen, whilst rearing was only seen on one occasion, as was licking the genitalia of a female, in both cases performed by a territorial male. Laufschlag was never witnessed. Mounting and copulation were also rarely observed, as shown in Table 3.

\section{Discussion}

The observed territorial behaviour is interesting in the light of previous research in eastern Africa. Mean territorial tenure is 67.25 days compared with 82.5 days found by Jarman (1979) in the Serengeti. Not only is mean territorial tenure shorter, but variation in tenure length is less. The maximum tenure of the present study was determined as 99 days compared with 267 days in eastern Africa. The minimum territorial tenure observed in the present study was 23 days compared with 5 days in East Africa. This is a similar tenure length to the 7.5 days averaged by the two rams who held territories during the rut period only, but who were not observed for more than 10 days. This fits with the theory that seasonality in southern Africa results in a shorter breeding season, which is reflected in shorter rut and territorial tenures.
First observed mating occurred on 16 May, and first lambs were born on 29 November, 197 days later, consistent with the 196 days of gestation suggested by Fairall (1969). Therefore, the first conception occurred 9 days after full moon, exceeding the 6 days stated by Murray (1982a). Although this is a small difference, there is no evidence to support the role of the lunar cycle, and thus daylength is the primary proximate factor, as noted by Skinner \& Van Jaarsveld (1987). It is also interesting that three rams set up their territories early during February, and yet all lost them during the rut before or on the day of the first recorded mating. This is contrary to the observations of Murray (1982a) that relations between territorial rams stabilize with the onset of mating. Therefore, setting up territories early in the year did not guarantee mating opportunities. Perhaps, early territorial rams are younger ones that have not yet developed the characteristics necessary to hold a territory during the most competitive period of the rut. It is possible that success in setting up early territories is also dependent on factors such as rainfall and therefore nutrition.

Unlike the observations of Leuthold (1970) and Murray (1982a), it seems that mating in impala is not exclusively limited to territorial rams, as one was by an aspirant. This ram was certainly not territorial, but instead benefited from a 'sneak' mating as the territorial male was busy protecting the main female herd. 
Mounting by another aspirant male, as well as by juvenile males was seen. The latter mounted ewes that had just been mounted or mated by the territorial male in the female herd in which they still resided. Although they perform this innate mounting behaviour, they are not yet sexually mature (Hanks et al., 1976), and therefore did not show hormone-driven sexual behaviour that would have resulted in their certain expulsion. In addition, flehmen was performed by territorial and bachelor rams, whilst rearing and genital licking by a territorial male were both seen on one occasion. Laufschlag was never witnessed in impala, confirming the fact that it was not an integral part of pre-mating behaviour, as reported in other antelopes (Jarman, 1979).

Home range size was $34.1 \pm 9.03 \mathrm{ha}\left(0.34 \mathrm{~km}^{2}\right)$ for territorial rams, and $58.8 \pm 33.35 \mathrm{ha}\left(0.59 \mathrm{~km}^{2}\right)$ for bachelor rams. These home ranges are lower than those described, the nearest of which is the 92-170 ha $(0.92$ $1.7 \mathrm{~km}^{2}$ ) in Zimbabwe (Murray, 1982b). The study site may lead to some underestimation in the home range size because of restricted vision of impala on the slopes. Importantly, there is no significant difference between the home range size of territorial and non-territorial rams because of the large variance, so when not territorial, all rams inhabit a similar range area. Territorial areas were found to be $21.0 \pm 11.27 \mathrm{ha}\left(0.21 \mathrm{~km}^{2}\right)$ compared with $50 \mathrm{ha}\left(0.5 \mathrm{~km}^{2}\right)$ calculated by Murray (1982b), and $42-$ 45 ha $\left(0.42-0.45 \mathrm{~km}^{2}\right)$ estimated by Jarman (1979). The territory size is significantly smaller than the home range of territorial rams, showing that when a ram is territorial, its movement is clearly restricted.

There were four main territorial areas in the study site, which the eight main territorial rams held, four earlier and four later in the rut. The position of territories remained the same throughout the year, suggesting that territorial boundaries are rigid, as noted by Novellie (1975) in blesbok (Damaliscus pygargus phillipsi Harper). Each territory was based around a large open area that contained abundant grazing and ecotone, the preferred habitat of impalas. This also reflects easier anti-predator vigilance by the impala, and observation by the researcher. Three of the four rams holding territories in the later part of the year all had larger territories than their predecessors in the same territory. This reflects the need for rams to visit the waterhole (and salt lick present there) more often during the dry season. Dasmann \& Mossman (1962) infer that all territorial rams have to visit water holes daily, and thus this acts as a neutral territory. This would benefit both bachelor and territorial rams which need water and would otherwise compete fiercely for access. Bachelor rams inhabited all parts of the study site, showing individual variation but not consistent restriction from certain areas. Bachelor rams seem to be tolerated wherever they are in whatever season, providing they do not show interest in ewes.

The method of territory loss is also important. The last four rams which took over territories during the rut, simply relaxed their territoriality around the end of July to the beginning of August, reducing their aggressiveness towards other rams. This compares with two territorial rams that were observed being chased off their territories earlier, once by a non-territorial ram, and once by a neighbouring territorial ram which later that day, subsequently lost its territory after a fight. Aspirant behaviour was observed for an average of 6.13 days. Rams in four of these cases subsequently became territorial, but in three cases, the ram left the area or returned to bachelorhood. This behaviour coincided with an influx of a number of new rams in the study site during the rut and with their increased interest in ewes. Indeterminate behaviour observed in five rams averaged 6 days. Jarman (1979) observed that re-integration with bachelors was usually gradual, and found that the longer the territorial tenure, the more likely the ram was to rejoin the bachelors quickly. There is evidence of a similar inverse relationship, with one ram having a territorial tenure of 23 days and an indeterminate period of 15 days, as opposed to three others which had territorial tenures of 80,99 and 88 days, with indeterminate periods of 6,6 and 2 days respectively.

Chasing plays an important role in the herding of ewes and the defence of a territory against other rams, as territorial rams chase other impala more than bachelors, and are chased by other rams less. In the same way, roaring is performed almost exclusively by territorial rams, indicating its importance in territorial defence, and to advance the onset and synchronization of oestrus in ewes, as suggested by Skinner, Jackson \& Marais (1992). Sparring was only seen amongst bachelors and then only really during the non-rut period, because of the danger of this activity escalating into a fight which is generally avoided due to the risk of injury. Instead, while both territorial and bachelor rams were seen to be involved in display performances, only rarely did this escalate into fights. Though no serious injury was seen to be inflicted, J. D. Skinner (pers. comm.) observed two dead rams in the rut in Botswana and another in Kwazulu-Natal, South Africa, with punctured abdomens resulting from fights with other rams, a fate which also befell a black impala ram at Touchstone Game Ranch. This suggests that in some cases injury and resulting deaths may be more prevalent, but are not always noticed because of the removal of the carcass by scavengers.

Some other behaviours differed between territorial and bachelor rams. Bachelors appeared to browse far more 
than territorial rams during the non-rut and clearly when the rut is ignored. This confirms previous findings that the restriction of bachelors to less good grazing areas means they have to browse more on dicotyledons (Anderson, 1972; Van Rooyen \& Skinner, 1989). It also reflects the fact that territorial rams have less time to browse than bachelors when grazing is scarce, because of the time taken up by territorial patrol and herding ewes. Territorial rams do not partake in allogrooming as they do not associate with other rams, and they also orally groom less during the rut, thus supporting a higher density of ticks than either bachelor rams or ewes (Mooring et al., 1996). It is possible that the larger tick burden and the associated irritation play a role in the decline in body condition of territorial rams. This eventually results in loss of territory to another ram.

The territorial system evident during southern Africa's short breeding season is fundamental to the reproductive activity and success of the impala, and this causes rams to compete for ownership of territories, whilst suffering a number of costs that affect their condition and ultimate health. It is possible to conclude that, in a small area such as the study site where rams defend resources to secure mating rights, one would expect at least four main territories based around important features such as water, and at least eight rams which will be territorial at some point during the rut. Although succession was observed in all four territories, it can only be speculated that this was determined by loss in body condition, and subsequently libido by the incumbent. Lone rams are likely to be territorial, and removing them during the rut may lead to instability and therefore possible reduced fecundity.

\section{Acknowledgements}

We thank Mr D. Methven for his kind permission to work at Touchstone Game Ranch, and the Reserve Manager Mr W. Erasmus for his logistical support. Dr M. Van der Linde and Prof. H.T. Groeneveld helped with behaviour analysis and statistical advice. Funding was provided by the Faculty of Veterinary Science Research Committee, personal research account (JDS), while CMO held a Rotary Ambassadorial Scholarship.

\section{References}

Anderson, J.L. (1972) Seasonal changes in the social organisation and distribution of the impala in Hluhluwe Game Reserve, Zululand. J. S. Afr. Wildl. Manage. Assoc. 2, 16-20.

Boulanger, J.G. \& White, G.C. (1990) A comparison of home-range estimators using Monte Carlo simulation. J. Wildl. Manage. 54, 310-315.
Dasmann, R.F. \& Mossman, A.S. (1962) Population studies of impala in Southern Rhodesia. J. Mammal. 43, 375-395.

Fairall, N. (1969) Prenatal development of the impala Aepyceros melampus Licht. Koedoe 12, 97-103.

Hanks, J., Cumming, H.M., Orpen, J.L., Parry, D.F. \& Warren, H.B. (1976) Growth, condition and reproduction in the impala ram (Aepyceros melampus). J. Zool. Lond. 179, 421-435.

Hofmann, R.R. \& Stewart, D.R.M. (1972) Grazer or browser: a classification based on the stomach structure and feeding habits of East African ruminants. Mammalia 36, 226-240.

Hooge, P.N. \& Eichenlaub, W.M. (1998) Animal Movement Extension to ArcView version 1.1. Alaska Biological Science Center, U.S. Geological Survey,

Anchorage, AK Available at http://0www.absc.usgs.gov.innopac.up.ac.za:80/glba/gistools

Jarman, M.V. (1979) Impala Social Behaviour, Territory, Hierarchy, Mating and the Use of Space. Parey, Hamburg . 1-93

Jarman, M.V. \& Jarman, P.J. (1973) Daily activity of impala. E. Afr. Wildl. J. 11, 75-92.

Leuthold, W. (1970) Observations on the social organisation of impala (Aepyceros melampus). $\mathrm{Z}$. Tierpsychol. 27, 693-721.

Mooring, M.S., McKenzie, A.A. \& Hart, B.L. (1996) Role of sex and breeding status in grooming and total tick load of impala. Behav. Ecol. Sociobiol. 39, 259266.

Murray, M.G. (1982a) The rut of impala: aspects of seasonal mating under tropical conditions. $\mathrm{Z}$. Tierpsychol. 59, 319-337.

Murray, M.G. (1982b) Home range, dispersal and the clan system of impala. Afr. J. Ecol. 20, 253-269.

Novellie, P.A. (1975) Comparative social behaviour of springbok, Antidorcas marsupialis (Zimmermann, 1780), and blesbok, Damaliscus dorcas phillipsi Harper, 1939, on the Jack Scott Nature Reserve, Transvaal. MSc Thesis, University of Pretoria, Pretoria

Seaman, D.E. \& Powell, R.A. (1996) An evaluation of the accuracy of kernel density estimators for home range analysis. Ecology 77, 2075-2085.

Skinner, J.D. \& Skinner, D.C. (2001) Significance of aseasonal breeding in arid adapted antelope in southern Africa. In: Ecology of Desert Environments (Ed. I. Prakash). Scientific Publishers (India), Jodhpur , 391403.

Skinner, J.D. \& Smithers, R.H.N. (1990) The Mammals of the Southern African Subregion, 2nd edn. University of Pretoria, Pretoria

Skinner, J.D. \& Van Jaarsveld, A.S. (1987) Adaptive significance of restricted breeding in southern African ruminants. S. Afr. J. Sci. 83, 657-663.

Skinner, J.D., Jackson, T.P. \& Marais, A.L. (1992) The 'ram effect' in three species of African ungulates. In: 
Ongules/Ungulates 91 (Eds F. Spitz, G. Janeau, G. Gonzalez and S. Aulagier). SFEPM-IRGM, Toulouse Van Rooyen, N. \& Bredenkamp, G. (1996) Waterberg Moist Mountain Bushveld. In: Vegetation of South Africa, Lesotho and Swaziland (Ed. A. B. Low and A. G. Rebelo). Dept. Environmental Affairs and Tourism, Pretoria
Van Rooyen, A.F. \& Skinner, J.D. (1989) Dietary differences between the sexes in impala (Aepyceros melampus). Trans. Roy. Soc. S. Afr. 47, 181-185.

Worton, B.J. (1987) A review of models of home range for animal movement. Ecol. Mod. 38, 277-298. 